\title{
ПОЛОЖЕНИЕ ПРАВОСЛАВНОЙ ЦЕРКВИ В ПОЛЬШЕ (20-30-Е ГГ. ХХ В.)
}

\section{А. И. Ёлкин}

Йолкін А. І. Становище православної церкви в Польщі (20-30-ті рp. ХХ ст.). В статті розглянуто становище Православної Церкви в Польщі в 20-30-ті рр. XX ст. Особлива увага приділена процесу зміни ії правового статусу і боротьбі за збереження церковної власності, підготовці кадрів духовенства, виданню релігійної літератури; проаналізовано процес українізації Православної Церкви на Волині.

Ключові слова: Православна Церква; автокефалія; Польща; ревіндикація.

Ёлкин А. И. Положение православной церкви в Польше (20-30-е гг. XX века). В статье рассмотрено положение Православной Церкви в Польше в 20-30-х гг. XX века. Особое внимание уделено процессу изменения ее правового статуса и борьбе за сохранение церковной собственности, подготовке кадров священнослужителей, изданию религиозной литературы; проанализирован процесс украинизации Православной церкви на Волыни.

Ключевые слова: Православная Церковь; автокефалия; Польша; ревиндикация.

Elkin A. I. The position of the Orthodox Church in Poland (20s-30-s of 20 ${ }^{\text {th }}$ century)

The article deals with the position of the Orthodox Church in Poland in the 1920s-1930s. Particular attention is paid to the process of changing its legal status, shows the struggle for the preservation of church property, training of clergy, the publication of religious literature, as well as to analyze of the process Ukrainization of Orthodox Church in Volyn.

Keywords: Orthodox Church; autocephalous; metropolitan; Poland; revendication.

Воссозданное в ноябре 1918 г. польское государство являлось многонациональным. Население страны в 1921 г. насчитывало 27161 тыс. человек. Поляков - 18629 тыс. чел. $(68,6 \%)$, других национальностей -8531 тыс. чел. $(31,7 \%)^{1}$. На ее территории, главным образом в восточных воеводствах, проживало около 3,8 млн. православных, в том числе 1,5 млн. украинцев, 1 млн. белорусов; 700 тыс. чел. на вопрос о своей национальности отвечали «тутешние»². Оказавшись на территории нового государства, они рассчитывали на моральную и материальную поддержку Православной Церкви (далее - ПЦ), которая сама находилась в сложной ситуации.

Положения Православной Церкви в Польской Республике, ее роли в жизни мирян одним из первых коснулся украинский эмигрант Д. Дорошенко ${ }^{3}$. Современный исследователь Е. Савчук издал книгу о национально-церковном движении на Волыни в 20-30-е гг. XX ст. ${ }^{4}$. Особенно следует отметить статью В.Т. Борщевича ${ }^{5}$, где рассматривается эволюция волынского православного духовенства как социальной группы в межвоенный период, а также его докторскую диссертацию, содержащую обстоятельный анализ жизни и деятельности православного духовенства Волыни с начала ХХ в. до 1991 года 6 . В диссертации подробно освещены различные аспекты борьбы за украинскую церковь в 20-30-е годы ХХ ст. И.А. Попов ${ }^{7}$ и А.К. Свитич ${ }^{8}$ больше акцентируют внимание на взаимоотношениях Православной Церкви и Польского государства. В статье российского исследователя С.В. Ольховского ${ }^{9}$ изучен процесс становления правового статуса Православной Церкви в межвоенные годы. Польский историк М. Папержинская-Турек доказывает, что политика возрожденной Польши по отношению к православным преследовала цель обеспечить интеграцию восточных крессов в новое государство ${ }^{10}$. Аналогичной точки зрения придерживается А. Миронович ${ }^{11}$. Несмотря на то, что поднятый нами вопрос получил освещение в отечественной и зарубежной литературе, он требует дальнейшего исследования. Детальнее следует изучить вопрос о правовом положении Православной Церкви в Польше и ее борьбе за автокефалию. Заслуживает углубленного исследования деятельность православного духовенства и мирян, направленная на защиту и сохранение церковной собственности, процесс украинизации и кадровая политика ПЦ, ее издательская деятельность. 
Православная Церковь в Польше подверглась серьезным испытаниям в годы Первой мировой войны. Значительная часть клира эвакуировалась в Россию, потом последовали революции, Гражданская война и советско-польская война 1919-1920 гг. Церковь начала восстанавливаться к началу 20 -х годов XX в., руководствуясь решением Всероссийского Церковного Собора об организации Православной Церкви в границах бывшего Царства Польского от 25 августа 1918 г. В постановлении подчеркивалось, что Православная Церковь в Польше является автономной составной частью Русской Православной Церкви ${ }^{12}$.

Однако ее положение в стране оказалось неоднозначным. В Польше имелось несколько православных епископов, но отсутствовал единый церковно-административный центр. В Варшаве епископа не было. Епископ Белостокский Владимир ведал Варшавско-Холмской епархией. Самой большой Волынской епархией управлял епископ Кременецкий Дионисий. Виленская епархия управлялась архиепископом Елиферием, Пинская - епископом Пантелеймоном; в Яблонецком монастыре жил викарий епископ Сергий ${ }^{13}$. Православное духовенство, в том числе и высшее, оказалось представлено в значительной степени выходцами из Российской империи, в целом являясь носителями монархических идей. В изменившейся ситуации церкви пришлось отстаивать свой статус в государстве, защищать церковную собственность и приспосабливаться к новой обстановке.

На повестку дня в качестве первоочередного встал вопрос об урегулировании взаимоотношений между Православной Церковью и Польской республикой. С этой же целью инициативная группа во главе с депутатом сейма Н.С. Серебрянниковым создала в 1921 г. Православный Церковный Совет (далее - ПЦС), выступивший инициатором проведения съезда православных приходов в Польше. В повестку дня были включены вопросы правового положения ПЦ в стране, организации церковно-общественных органов, функционирования приходов и другие. Польские власти дали разрешение на его проведение, однако съезд не состоялся ${ }^{14}$. Против его организации выступил епископ Кременецкий Дионисий. Он опубликовал заявление с критикой программы, предложенной съезду ПЦС, протестуя против его попытки узурпировать право говорить от имени Православной Церкви Польши ${ }^{15}$. Кроме того, Дионисий запретил православному духовенству Волыни участвовать в этом съезде.

Правительство, выступившее за установление автокефальной ПЦ в стране, решило воспользоваться расколом среди православного духовенства. Министр исповеданий Ратай пригласил Дионисия в Варшаву и предложил ему разработать проект организации Высшего управления ПЦ в Польше, что епископ и сделал. Кабинет министров, зная позицию большинства епископов, не мог рассчитывать на их поддержку в провозглашении автокефалии. Поэтому он пригласил из Италии бывшего архиепископа Минского Георгия, добившись от Московского патриарха Тихона утверждения этого иерарха митрополитом в Польше ${ }^{16}$. Архиепископ Георгий создал в 1921 г. орган высшего церковного управления страны - Синод, в состав которого вошли все имевшиеся епископы ${ }^{17}$. Правительство представило Синоду проект закона об взаимоотношениях между Православной Церковью и государством. Несмотря на то, что проект Синод отклонил, 30 января 1922 г. правительство в одностороннем порядке опубликовало «Временные правила», которые давали ему возможность вмешиваться во внутреннюю жизнь церкви. Назначение, перемещение и увольнение епископов возможно было лишь по решению Синода, но при предварительном согласовании с властями. Все епископы присягали на верность государству. Кадровые вопросы в приходах находились также под контролем властей ${ }^{18}$.

С канонической точки зрения провозглашение автокефалии светской властью недостаточно, ибо, во-первых, этот шаг является прерогативой церковного права, определявшего статус данной церкви в составе Вселенской церкви, а не в рамках государства; во-вторых, следовало получить разрешение главы и епископата той церкви, в состав которой ранее входили приверженцы автокефалии. Такая политика польских властей и поддерживающего ее Дионисия вызвала протесты некоторых епископов. В марте 1922 г. архиепископ Елеферий, епископы Владимир и Сергий направили патриарху Тихону подробный доклад, в котором подчеркивалось: Синод фактически ввел автокефалию, а это означало полное подчинение местной Церкви светской власти ${ }^{19}$.

Между тем, польские власти, дабы фактически покончить с оппозицией среди епископата, прибегли к репрессиям. Епископа Пантелеймона, поляка по национальности, отказавшегося подписать «Временные правила», заключили в Мелецкий монастырь. Архие- 
пископа Елеферия, епископов Владимира и Сергия выслали из страны на том основании, что они, как иностранцы, занимались скорее политической, нежели духовной деятельностью ${ }^{20}$. Впрочем, эти превентивные меры по ограничению влияния строптивых иерархов не шли ни в какое сравнение с гонениями на религию и церковь в Стране Советов, где большевики в апреле 1922 г. арестовали и заключили в тюрьму патриарха Тихона и образовали еще один ЦК - Церковный Комитет*. После этих событий Польское правительство с целью подчинения и контролирования ПЦ, а также ее кадровой политики, настояло на скорейшем провозглашении автокефалии ПЦ, ссылаясь на прекращение в Москве канонической церковной структуры и недопустимости для Польского государства, чтобы ПЦ в Польше находилась в зависимости от безбожной власти, по указке которой действовал образовавшийся в Москве Церковный Комитет ${ }^{21}$. События в Москве привели к тому, что на заседании Синода 14 июня 1922 г. под председательством митрополита Георгия, при участии представителя государственной власти была объявлена автокефалия Православной Церкви в Польше ${ }^{22}$. Однако радикальная часть духовенства расценила деятельность митрополита Георгия как измену православию, и его застрелил архимандрит Смарагд со словами: «Вот тебе, палач Православия!» 23 .

После этого главой ПЦ в Польше стал Дионисий. Начало его деятельности ознаменовалось массовыми протестами рядовых прихожан. В июле 1923 г. Синод ПЦ в Польше поставил перед правительством вопрос о том, чтобы служащие в государственных учреждениях, равно как и состоящие на службе солдаты православного исповедования, освобождались от нее в церковные православные праздники. В ответ на это обращение Министерство исповеданий предложило Дионисию рассмотреть в Синоде вопрос о переходе с юлианского на григорианское календарное летоисчисление. С согласия всех епископов это произошло 12 апреля 1924 г., но не было воспринято паствой. Православное население в знак протеста перестало посещать храмы в те дни, когда священники совершали богослужение по новому стилю, продолжая отмечать праздники по-старому. Поэтому в августе 1924 г. Синод отменил апрельское постановление ${ }^{25}$.

Вопрос об автокефалии ПЦ в Польше, волновавший мирян, часто становился предметом дискуссий на страницах прессы. Так, в варшавской эмигрантской газете «За свободу» от 11 ноября 1924 г. появилась статья главного редактора Д. Философова «Православие в Польше». В ней автор писал: «Если вы говорите, что нужно освободиться от Москвы (Тихон) и Югославии (Антоний), то утверждают, что вы действуете на руку полякам и Католической Церкви. Если же вы против автокефалии и за подчинение патриарху Тихону, то вы попадете в следующие, почти непреодолимые затруднения. Во-первых, вы не знаете, где заканчивается власть Тихона и начинается власть большевиков. Эта неизвестность и заставила Синод в Сремских Карловцах поставить вопрос об автокефалии Русской Православной Церкви за границей. Во-вторых, борясь против автокефалии, вы должны непременно пойти на союз либо с Антонием (Храповицким) - первым главой Русской Православной Церкви за границей, либо с митрополитом Евлогием (Георгиевским) (Русское архиепископство Парижское). Но для демократов такой союз невозможен. Как могут они, тщательно отмежевываясь от монархических течений, в то же время быть в союзе с царским епископатом? Не надо быть вовсе «другом» поляков, надо быть просто здравомыслящим человеком, чтобы понять, что ссылаться на авторитет Евлогия или Антония для защиты Православия в Польше - значит вредить Православию. Тогда на кого же опираться? Вопрос остается без ответа. И пока принципиальные вопросы висят в воздухе, миллионы мирян и местное духовенство должны выносить на своих плечах все следствия центральной разрухи» ${ }^{26}$.

Поскольку согласия на автокефалию со стороны Московского патриархата получить не удалось, Дионисий и его сторонники стали искать выход из создавшейся ситуации. Польский православный епископат решил воспользоваться правом единства Вселенской

* Большевики развернули невиданный по жестокости террор против РПЦ. По оценкам некоторых историков, в 1920-1930-е гг. было расстреляно и доведено до смерти более 200000 служителей церкви. Около полумиллиона православных священников было брошено в тюрьмы или отправлено в ссылку. К 1939 г. в СССР остались незакрытыми около 100 храмов из почти 60000 действующих в 1917 г. - См.: www.Каспаров.ru./material.php?id=55Ao9D5140C3D $\rightarrow$ Доступ от 17.07.2015. 
церкви и обратился с подобной просьбой к Константинопольскому патриарху, называемому также Экуменическим (Вселенским). Автокефалия провозглашалась на основе «томаса» - особого акта, полученного от патриарха Григория VIII. 13 ноября 1924 г. Польша заплатила за «томас», признававший автокефалию Православной Церкви в стране, 12 тыс. фунтов стерлингов, выдала 30 тыс. швейцарских франков на расходы патриаршей делегации, которая привезла этот «томас», и выплачивала постоянно денежное вознаграждение четырем «особенно благожелательным к ее делам сановникам патриархата» ${ }^{27}$. Окончательно автокефалию приняли в 1925 г.

Следовательно, провозглашение автокефалии ПЦ в Польше означало признание ее статуса государством. До этого положение ПЦ и права верующих определялись 110 и 114 статьями Конституции 1921 г. и формально соблюдался принцип равенства конфессий при сохранении ведущей роли Католической Церкви - далее КЦ 28 . Особый статус Костела в государстве был закреплен в соглашении, заключенном польскими властями с Ватиканом.

10 февраля 1925 г. власти Второй Речи Посполитой подписали с Римским престолом конкордат, регулировавший отношения между государством и КЦ на принципах автономии и взаимодействия. Конкордат предоставил Католической и Униатской Церкви различные привилегии, которых не имели представители других конфессий. Соглашение гарантировало Католической Церкви независимость от светских властей и внутреннее самоуправление на основе канонического права. В отличие от других аналогичных договоров, конкордат с Польшей не содержал положения, что действия церкви не могут нарушать государственное законодательство. Польское государство лишалось права контролировать назначение на церковные должности; епископат же получил право контроля над преподаванием религии; одновременно вводилось обязательное изучение Закона Божьего в школах ${ }^{29}$.

Наряду с вопросом о статусе ПЦ, пришлось решать вопрос ее земельной собственности и храмовых зданий. В 1920 г. в Польше приняли закон об аграрной реформе, предусматривавший отчуждение и церковной земельной собственности. К 1924 г. оказалось конфисковано 20000 га церковных земель ПЦз3. Только на Волыни конфисковали почти $50 \%$ церковных и монастырских угодий ${ }^{31}$.

Но этим дело не ограничилось. С момента включения Холмщины и Подляшья в состав Польского государства началась кампания по обращению православных в католиков (неоуния). Во времена Первой Речи Посполитой украинское население региона принадлежало к униатам. После ликвидации царской властью Греко-Католической Церкви униаты Холмщины и Подляшья в большинстве своем стали православными. На этом основании польские власти утверждали, что местное украинское население является русифицированными поляками. Предпринимались меры для того, чтобы склонить православное население к переходу в католицизм. Однако эта кампания ожидаемых результатов не дала. Всего в католичество перешло около $1 \%$ православных ${ }^{32}$.

Бурные протесты среди приверженцев православия вызвали действия властей, поддержанные КЦ по ревиндикации (возвращению) некогда принадлежащего католикам имущества, переданного ПЦ администрацией Российской империи ${ }^{33}$. В результате такой политики у православных к середине 20 -х годов отобрали около 500 храмов, оставив $1948^{34}$. Новая кампания по возвращению собственности, утраченной Католической Церковью, началась весной 1938 года. В польской прессе появились статьи, авторы которых утверждали, что на Холмщине и Подляшье (Люблинское воеводство) много ветхих и «ненужных храмов, ибо там нет верующих» (эти регионы до 1914 г. входили в состав Российской империи). Кроме того, в целом ряде городов и селений Холмщины состоялись т.н. «веча протестов», организованные Обществом развития восточных крессов Польши. На этих «вечах» принимались резолюции, осуждавшие православных священников, украинизирующих население Холмщины. В тех же резолюциях содержалось требование о ликвидации закрытых церквей, которые самим фактом своего существования портят добрые отношения между католическим и православным населением ${ }^{35}$. В апреле 1938 г. по указанию местной администрации разрушили 114 храмов, в т.ч. 58 закрытых и 56 действующих. Разборка производилась под руководством старост и полицейских особыми отрядами рабочих при участии местного католического населения.

Действия польских властей вызвали массовые акции протеста как в стране, так и за рубежом. С обширным архипастырским посланием, осуждающим действия правительства 
по разрушению храмов, выступил митрополит А. Шептицкий, предстоятель Униатской Церкви ${ }^{36}$. Известный публицист С. Мацкевич, редактор виленской газеты «Слово», поместил 11 августа 1938 г. статью, в которой писал, что дело 4 млн. православных, составляющих $11 \%$ населения Польши, не является вопросом, который можно было бы разрешить конфискациями; скоро весь польский народ почувствует следствия ошибок, вытекающих из легкомысленной политики правительства. И, если бы автор статьи, писал он, являлся депутатом сейма, то внес бы предложение о предании его членов суду ${ }^{37}$. С возмущенными речами выступали в сейме оппозиционные депутаты, в частности, украинский священник из Волыни Волков ${ }^{38}$.

Разрушение церквей на Холмщине и в Подляшье получило широкий резонанс за границей и вызвало протесты со стороны русской эмигрантской Церкви. На Соборе в Сремских Карловцах (13-25 августа 1938 г.) были заслушаны два посланца из Польши: К.Н. Николаев с докладом «Катастрофа православия в Польше» и отец Гриненко (Попов) с докладом «Меморандум православного духовенства в Польше». Собор принял предложение архиепископа Виталия из США, чтобы каждый участник Собора после возвращения домой осуществил акции по ознакомлению общественности и правительств своих стран с фактами насилия в отношении православия в Польше ${ }^{39}$. В начавшейся антипольской кампании критике подверглись не только варшавские власти, но и Синод Православной Церкви во главе с Дионисием за то, что он утратил независимость по отношению к правительству. К обвинениям Дионисия присовокупили и то, что он проводил «полонизацию» и «католизацию» православных и раскалывал православие ${ }^{40}$. Глава Болгарской Православной Церкви митрополит Стефан, протестуя против преследования православных в Польше, вернул польскому правительству пожалованные ему в разные годы польские ордена ${ }^{41}$.

Важное место в процессе подчинения ПЦ Польскому государству занимала кадровая политика, призванная изменить функции церкви среди непольских национальностей. В письме министра вероисповеданий департаменту образования от 9 мая 1924 г. задача формулировалась следующим образом: «Чтобы у верующих воспитать дух польской государственности, необходимо взять под государственный контроль подготовку кадров приходского духовенства. Духовенство это не многочисленное, за редким исключением, противопоставляет себя изменившимся политическим требованиям и проявляет оппозиционность в отношении своего епископата, враждебность в отношении польской государственности... Чтобы изменить эту ситуацию, недостаточно мер, направленных в отношении духовенства (высылки за пределы страны), проводящего до сих пор антигосударственную политику. Государственные инстанции в процессе подготовки духовенства должны добиться его приверженности Польше, так как прежнее поколение было направлено против нее» ${ }^{42}$. Практически это выразилось в усилении государственного контроля над подготовкой церковнослужителей.

В середине 1920-х гг. в стране существовали духовные семинарии в Вильно и Кременце, а также мужское и женское духовные училища в Дермани на Волыни. После майского переворота 1926 г. началось реформирование семинарий с учетом потребностей польской государственности. Сроки обучения сократились с десяти до девяти лет, количество часов на богословские предметы уменьшилось со 100 до 50 в год. Обучение предусматривалось осуществлять на польском языке ${ }^{43}$. Однако выполнить в полной мере поставленную задачу не удалось, ибо после назначения в 1927 г. ректором Кременецкой семинарии П. Табинского она начала проводить проукраинский курс и готовить национально сознательных священослужителей ${ }^{44}$. Польские власти, оказывая ПЦ помощь в подготовке православных священников, добивались, чтобы в ходе учебно-воспитательного процесса им прививалось уважение к Польше. Главным центром подготовки православного духовенства стал богословский православный факультет Варшавского университета. Факультет торжественно открылся 8 февраля 1925 г. Это событие православные расценивали как акт доброй воли государства в отношении ПЦ. Преподавание на факультете осуществлялось на польском языке, много внимания уделялось изучению польской истории и культуры. Все это должно было помешать использованию ПЦ в качестве орудия русской и украинской политики. Факультет в 20-30-е гг. XX в. окончили несколько сот священнослужителей ${ }^{45}$.

Православная Церковь являлась объектом постоянного внимания не только со стороны польских властей, но и со стороны национальных меньшинств, и, в первую очередь, украинцев. Украинцы, проживающие главным образом на Волыни, пытались сделать 
ПЦ орудием национально-политической борьбы. В свою очередь, польские спецслужбы, военные и административные органы предпринимали попытки создать оплот полонофильского и враждебного России украинского национального движения на Волыни, которая до 1914 г. принадлежала империи Романовых и была включена в состав Польши по Рижскому договору в 1921 г. Начало борьбы за украинскую церковь положили решения Волынского епархиального съезда, проходившего осенью 1921 г. в Почаевской лавре $^{46}$. Съезд признал своевременным украинизировать церковь путем замены церковно-славянского на украинский богослужебный язык - там, где пожелают верующие. Кроме украинского языка, высшая церковная власть разрешила употребление белорусского, польского и чешского. Активную агитацию за украинизацию церкви развернул А. Рачинский, главный редактор журнала «На варті», издававшегося во Владимире-Волынском. Журнал призывал к разрыву с Московским патриархатом и его традициями ${ }^{47}$. Новым этапом в украинизации ПЦ на Волыни стало назначение на должность настоятеля Владимир-Волынского собора архимандрита Поликарпа (Сикорского). При нем на Волыни украинизировали $30 \%$ приходов ${ }^{48}$. Большую роль в украинизации сыграли украинские депутаты сейма и сенаторы, принадлежащие к Беспартийному блоку сотрудничества с правительством. При их участии (Бури и Скрыпника) 10 сентября 1933 г. во время праздника в честь Иова Почаевского состоялась демонстрация украинцев против церковного административного аппарата, построенного, как они считали, по образцу времен русского царизма. Манифестанты требовали снятия с Волынской кафедры митрополита Дионисия и назначения на его место епископа из украинцев. По всей Волыни прокатилась волна митингов, от имени участников которых посылались телеграммы правительству и президенту с требованием назначить на Волынь епископа-украинца. Реагируя на эти обращения, министр исповеданий в письме от 23 сентября 1933 г., направленном митрополиту Дионисию, потребовал от него освободить Волынскую кафедру и назначить на это место другого епископа ${ }^{49}$. В 1930 -е годы священников-русофилов окончательно удалили с ключевых церковных должностей в Волынской епархии ${ }^{50}$.

В межвоенной Польше Православная Церковь, являясь главным фактором духовного влияния на верующих, стремилась удовлетворить их потребности в религиозной литературе. В Холме, Кременце, Гродно, Вильно, а несколько позже и в Варшаве начинают печататься православные издания, предназначенные прежде всего для местного населения, в т.ч. русских и поляков. Главным образом, это были епископские послания по случаю различных церковных праздников, небольшие «слова» и «поучения» отцов церкви, отдельные главы из Евангелия ${ }^{51}$.

Но начало планомерной православной издательской деятельности начинается с открытия в 1923 г. синодальной типографии в Варшаве. Это был не только крупнейший православный издательский центр Польши, но и в восточнославянском мире в целом, наладивший выпуск литературы - от богословской до детской. До недавнего времени считалось, что Синодом было издано более 50 названий книг ${ }^{52}$. Однако скрупулезный подсчет, произведенный Л.Л. Щавинской, позволяет сделать вывод, что было издано свыше 400 названий ${ }^{33}$. Основная масса книг и брошюр напечатана на русском языке, но были также издания на польском и украинском. Тематика и содержание изданных в типографии работ являлась разнообразной. Произведения, написанные до революции и после переиздававшиеся, работы православных литераторов-эмигрантов, живших за границей, а также (анонимно) авторов из СССР. Публикуется много сочинений местных жителей, среди них представители русского или русскоговорящего меньшинства, часто светские лица, но близкие к церковным кругам. Отдельную группу публицистов составляли высшие духовные лица, преподаватели духовных заведений, приходские священники ${ }^{54}$. Уникальным изданием являлся журнал «Воскресное чтение». Он еженедельно выходил в Варшаве с 1924 по 1939 г., распространяясь не только среди православных Польши, но и в Русском Зарубежье.

Первостепенное внимание, естественно, уделялось печатанию православной литературы, включая большое количество разнообразных листовок. Тиражи этих изданий насчитывали от одной до нескольких тысяч экземпляров. В первую очередь следует отметить всевозможные календари и богогласники ${ }^{55}$, а также целые серии религиозной литературы на русском языке: «Библиотека Православного Христианина» (100 нумерованных 80-страничных выпусков); «Набожные песни из Богогласника» (около 100 выпусков), представляя 
из себя листки с текстами отдельных песнопений и нотами ${ }^{56}$; «Миссионерские листки» более 100 различных выпусков; восьмистраничные «Беседы об устройстве святого Храма и о совершаемых в нем Богослужениях». Отметим также серию противосектантских брошюр и книг, издававшихся на русском, украинском и польском языках в 1920-1930-е годы (до 30 -ти изданий $)^{57}$. Следовательно, синодальные учреждения Православной Церкви в Польше и, прежде всего, синодальная типография в Варшаве являлись настоящими литературными центрами, которые удовлетворяли духовные потребности верующих.

Окончательное урегулирование правового положения Православной Церкви в Польше было осуществлено президентским декретом от 18 ноября 1938 г. В этом документе отмечалось, что Православная Церковь в своем внутреннем устройстве полностью независима, но действует в рамках польского законодательства ${ }^{58}$. При издании нового церковного устава произошло переименование Православной Церкви в Польше в Польскую Автокефальную Церковь. По существу это был юридический акт, закрепивший интеграцию ПЦ в Польское государство.

${ }^{1}$ Maly Rocznik Statystucrny. - Warszawa, 1933. - S. 4.

${ }^{2}$ Ольховский C.B. Урегулирование правового статуса православной церкви в межвоенной Польше // Профессор МГУ И.М. Белявская: Материалы конференции, посвященной 90-летию со дня рождения профессора МГУ им. М.В. Ломоносова И.М. Белявской. - М., 2005. - С. 144.

${ }^{3}$ Дорошенко Д. Православна церква в минулому й сучасному житті українського народу. - Берлін, 1940. - $71 \mathrm{c}$.

${ }^{4}$ Савчук Б. За Українську церкву. Національно-визвольний рух на Волині у 20-30-ті рр. XX ст. - Івано-Франківськ, 1997. - 114 с.

${ }^{5}$ Боршевич В. Національна самоідентифікація православного духовенства Волині у 20-30-х pp. XX ст. // Науковий вісник Волинського національного університету. - Історичні науки. - 2009. № 13. - C. 185-192.

${ }^{6}$ Боршевич В. Православне духовенство Волині у XX столітті: автореф. ... докт. іст. наук. Львів, 2011. - 38 с.

${ }^{7}$ Попов А. Пора проснуться! Гонение на православие и русских в Польше в ХХ веке. - Белград, 1937. $-80 \mathrm{c}$

${ }^{8}$ Свитич А.К. Православная Церковь в Польше и ее автокефалия. - Буэнос-Айрес, 1959. - 231 с.

${ }^{9}$ Ольховский С.В. Урегулирование правового статуса... - С. 144-149.

${ }^{10}$ Papirzynska-Turek M. Miedzy tradycja, a rzeczywistoscia. Panstwo wobec prawoslawia 1918-1939. - W., 1989. - 481 c.

${ }^{11}$ Mironowicz A. Kosciol prawoslawny w Polsce. - Biatlystok, 2006. - 917 c.

${ }^{12}$ Papirzynska-Turek M. Micdzy tradycja, a rzeczywistoscia... - S. 140.

${ }^{13}$ Попов А. Пора проснуться!.. - С. 31 .

${ }^{14}$ Свитич А.К. Православная Церковь в Польше... - С. 18.

15 За свободу. - 1921. - 14 августа.

${ }^{16}$ Попов А. Пора проснуться!.. - С. 32.

${ }^{17}$ Там же.

${ }^{18}$ Ольховский С.В. Урегулирование правового статуса...-С. 145.

${ }^{19}$ Свитич А.К. Православная Церковь в Польше... - С. 31.

${ }^{20}$ Там же. - C. 32.

21 Там же. - С. 35.

22 Замойски Я.Е. Русская православная зарубежная церковь 1928-1938. По материалам польских заграничных служб // Новая и новейшая история. - 1998. - № 1. - С. 50.

${ }^{23}$ Свитич А.К. Православная Церковь в Польше... - С. 45.

${ }^{24}$ Там же. - С. 50.

${ }^{25}$ Там же. - С. 51.

26 За свободу. - 1924. - 11 ноября.

27 Замойски Я.Е. Русская православная зарубежная... - С. 52.

${ }^{28}$ Przymierze. - 1921. - № 11. - C. 38-40. C. 149 .

29 Дыбковская А. История Польши / А. Дыбковская, М. Жарын, Я. Жарын. - Варшава, 1995. -

${ }^{30}$ Кучерепа М. Церковно-релігійне життя українського православного населення Польщі (19211929 pp.) // Dzieje Podkarpacia. - T. 3. - Krosno, 1999. - C. 153.

31 Боршевич В. Православне духовенство Волині... - С. 26.

${ }^{32}$ Там же. - C. 27.

${ }^{33}$ Zdriechowski M. Wplywy rosyjskie na dusze, Polska. - Krakow, 1932. - S. 160. 
${ }^{34}$ Свитич А.К. Православная Церковь в Польше... - С. 15.

${ }^{35}$ Там же. - С. 73.

36 Дрозд Р. Історія українців у Польщі в 1920-1939 рр. / Р. Дрозд, Г. Гальчак, І. Мусиєнко. Харків, 2013. - С. 35.

${ }^{37}$ Slovo. - 1938. - 11 sierpnia.

${ }^{38}$ Боршевич В. Православне духовенство Волині... - С. 22.

39 Замойски Я.Е. Русская православная зарубежная... - С. 62.

${ }^{40}$ Государственный архив Российской Федерации (далее ГАРФ). Ф. 5814, оп. 1, д. 2, л. 45.

41 Дрозд Р. Історія українців у Польщі... - С. 35.

${ }^{42}$ Papierzynska-Turek $M$. Micdzy tradycja, a rzeczywistoscia... - S. 382-383.

43 Дрозд Р. Історія українців у Польщі... - С. 35.

${ }^{44}$ Там же.

45 Арсеньев Н.С. Дары и встречи жизненного пути. - Франкфурт-на-Майне, 1974. - С. 189-190.

${ }^{46}$ Боршевич В. Православне духовенство Волині... - С. 16.

${ }^{47}$ Свитич А.К. Православная Церковь в Польше... - С. 120.

${ }^{48}$ Там же. - C. 170.

${ }^{49}$ Боршевич В. Православне духовенство Волині... - С. 16.

${ }^{50}$ Свитич А.К. Православная Церковь в Польше... - С. 175.

${ }^{51}$ Цыпин В. История Русской Церкви. В 9 т. - Т. 9. - М., 1997. - С. 236-238.

52 Лабынщев Н.А. Народная литература Православной Польши: 1918-1939 гг. // Славяноведение. - 1996. - № 2. - С. 63-73.

${ }^{53}$ Mironowicz A. Kosciol prawoslawny w Polsce... - S. 150.

${ }^{54}$ Шавинская Л.Л. Книги и брошюры крупнейшего православного издательства межвоенной

Польши - Варшавской Синодальной типографии // Славяноведение. - 1996. - № 2. - С. 63-73.

55 Лабыниеев Н.А. Народная литература Православной Польши... - С. 67-68.

${ }^{56}$ Там же. - С. 70.

${ }^{57}$ Шавинская Л.Л. Народные листки, напечатанные Православной Церковью... - С. 77-82.

${ }^{58}$ Цылиин В. История Русской Церкви. - В 9 т. - Т. 9. - М., 1997. - С. 236-238. 